\title{
肝臓の電子顕微鏡 像
}

\section{高木交一鉿木昭男*}

\section{はじめに}

電子顕微鏡がその優れた分解能のゆえに細胞組 織学に拈ける劃期的な研究方法として用いられる ようになつてからすでに 10 数年を経て物り,これ に対応する輝かしい業績も今日まで数多く発表さ れている.種々の動物の肝臓の正常構造について 6 Dalton ら1飞よる初期の研究を始め少なから ざる報告2 13，58）があり，人の肝缄についても正

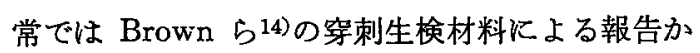
ら動物肝と全く同一の微細構造を示すことが確か められている.しかしこれら諸報告の多くは一般 肝細胞, 類洞㔚よび Disse 氏腔, 星状細胞等飞集 中し小葉の全貌については現在な敌不明な点が多 多残されている.また，正常肝細胞自体の搆造に ついて小葉内の各帯(中心帯・中間帯・周辺帯) に打仔差異, ないしは食慨摄取に伴う量的, 質 的, 時間的な考慮即ち生理的変動を充分に観察し た報告は少ない。これは観察技術の困難なことに あよるが，しかし今後行なわれるべき病的細胞の 詳細な観察への基礎として充分に且つ可及的速や かに解決されねばならない重要な問題である。

如上の観点から筆者らは生理的变動をも含めた 肝葴の正常微細構造と種々な食䬲組成の差による 肝細胞像の変化を電顕的飞比較検討しつつあるが 本稿では正常な動物の肝蔵の電䫓的一般構造, 特 飞従来あまり注目されていない中心静脈, 門脈領 域, 胆管膨大部等の構造に関するわれわれの知見 を写真によつて略述し，また食餌の量的・質的影 響による肝細胞像の変動についての所見の概略を 紹介してみたいと思う。

\section{健常な動物肝䁍の一般的構造}

写真1，2，3はそれぞれ質的なよび量的に充分な各

* F. Takagi (教授), T. Suzuki : 東京蒸恵会医科大学 病理学教室.
種栄盖素と水とを飽食せしめ $20^{\circ} \mathrm{C}$ の恒温室で飼育した ウィスター系雄ラッテ (188 g)（高木，'59)15) の肝小葉 の中間帯, 周辺帯, 中心帯の肝細胞群を示す弱拡大写真 である. 写真 1 では多数の肝細胞が相接して配列しその 間を類洞 (S) が不規則に貫通している. 類洞腔に面し た肝細胞表面には無数の指状細胞質突起即ち Microvilli (Mv)が密生し, 類洞壁を形成する内皮細胞 (Edc) の薄 層および Kupffer 氏星状細胞(この写真には示されてい ない）との間に Disse 氏腔 (Ds) が形成されている. これに対し直接肝細胞同志が相接する部分では極く少数 のホック様細胞岸合2)と少数の Microvilli を伴つた細 胞間接の拡大部即ち毛細胆管 (Bc) (後述, 写真 4,5 参照）とを除いては隣接する二細胞膜の走行は比校的平 滑である.肝細胞は 1 個, 時に 2 個の頑球形核 (N) と 1 ないし2，3個の核小体をむち細胞質は豊富で多数の糸 粒体 (M), 豊富な小胞体 (REr, SEr), Golgi complex (G) 等各種の恒在性小器官を始め, 脂肪滴, 分泌顆粒, フェリチン顆粒等の種々な構造物およびこれらの間を埋 める淡明な領域が認められる. 写真 2 は周辺帯, 写真 3 は中心帯を示すが写真1〜3を通じて明らかなように肝 細胞には一見して細胞質に淡明な領域が存在し全体とし て明調なもの（明調細胞）(Cc)（写真 $1 ， 2 ， 3$ ), 淡 明な領域が全く認められずまた全体として甚だ暗いもの (暗調細胞) (Dc)（写真 $2 ， 3$ ），扰上び両者の中間に属 するむの（中間調細胞）(Ic）(写真 1) の 3 種があるこ とが注目される.この肝細胞の暗調を特徽づける要素と しては後述する Glycogen 領域がほとんどないこと， 滑面小胞体拉よび遊離 Palade 顆粒の豊富な事等が挙げ られ，また位置的には中心带および周辺帯に比較的多く 認められるようであるが中間帯においても時にほぼ定型 的と思われる暗調細胞が明調細胞と突然に隣接している 像をみることがある.なおこれら肝細胞内小器官の基本 的變細構造についてはそれぞれ多数の原著があるのであ らためて詳述することは避け，特に肝細胞に和ける特徽 のみを以下写真を中心に紹介してみたいと思う。

\section{肝細胞の微細構造概略}

A. 核 
$2: 2$

肝

写真 4 は写真 1 と同一例の中間带肝細胞(中間調細胞) を示したもので核（N）は平行する内外 2 層の核膜 $(\mathrm{Nm}) 16$ 18) により細胞質と境される，核内部は中等度 の電子密度をもら, 微細顆粒状ないし短フィラメント 状19)(值径約 $170 \mathrm{~A}$ )20)を旺する構造とこれに混在して さらに大きく且つ電子密度の高い暗い顆粒状構造21)に よつて满たされ後者はしばしば多数凝集してやや粗大な 顆粒を作つている.これら核物質の分斾は一般にほぼビ マン性であるが，時には従来光学的にいわれたクロマチ ン網を瞀わしめるような不規則な分布を示するのもある (写真 $1 \sim 4$ 比較参照). 核小体 (写真 $2, \mathrm{Nl}$ ) は Estableら22)そのた23〜26)によつていわれているよらに，電 子密度の高、微細顆粒が凝集して不規則に縓絡した紐状 構造 (Nucleolonema)を呈するものが多く，その間を埋 める Pars amorphaは一見核質の明るい力の顆粒之区別 しえないよらな維細で中等度の電子密度をもつた顆粒状 構造から構成されている，核小体には限界膜は諗められ

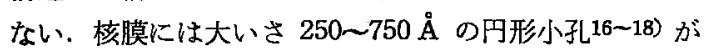
多数存在しまたこれを通じての核と細胞質との間の物 質交流像27)も報告されている.外側核膜はしばしば膨出 して粗面小胞体（後述）と連絡像16)を示すことがある.

\section{B. 系粒体と Microbody}

絃粒体の一般微細構造については Palade28,29) および Sjöstrand30)の研究により写真 6 に示すごとく内・外2 重 の糸粒体膜 $(\mathrm{Mm})$ ，糸粒体基質 $(\mathrm{Ms})$ ，糸粒体顆粒 $(\mathrm{Mg})$ および内䋛体膜の “ひだ”とての Cristae mitochondriales (C) の存在が明らかにされている. それらの 詳細についてはそれぞれの原著および Cedergren31を 始めとするその後の多数の論文を参照せられたい．旰細 胞の糸粒体としては長桿状, 短桿状, ヒョウタン型, 球形 ときに輸状および分岐状等種々の形のものがみられるが Noël ら32,33)の古典的研究以来いわれてきたようにその 形と分布については電顕的にも周辺带細胞には球形のも のが多く，中心帯に近づくはど細桿状のものが比較的多 数望められるが同一帯に和ける明・暗調細胞の間には形 の上での著るしい差異はあまり㶵められない(写真 1,2 , 3 比較参照). 内部構造では糸粒体顆粒写真 $6(\mathrm{Mg})$ が 毎常認められること，横断面所見で輪状 (写真 6 矢印) を旺することからCristae の形は“ひだ”といらよりはむ しろ指サック状を呈すること等であろう，細胞質中には 系粒体より小型 $(0.2 \sim 0.5 \mu)$ で約 $60 \AA$ の単尿被膜に より团衣，系粒体基質上り暗い均質微細顆粒状の内容 とこれよりさらに暗い core とをもつた類球形小体が少
2 巻 1 号 (1960)

なからず夾出される(写真 4，Mb)，これはRhodin35) 和よび Rouiller 534)により糸粒体の前段階搆造である と考えられたが高木15)，萩原36)；Takaki37)によつてさ らにこのものが滑面小胞体より形成されることが明らか にされている.

系粒体が細胞の代謝に関係ある重要な酵素群を豊富に 含むことはよく知られているが，その中でも特に重要な クエン酸回路や酸化的烸酸化に関する醭素系，チトク口 一ム系酵素群などが前述“Cristae” の部分に局在する ことは興味深い事実である65).

\section{C. 小胞体}

この構造は始めPorter ら38,39)により発見されたがそ の後の Palade 54,28.40-42), Weiss43), Sjöstrand44) そ. のたの優れた研究および本邦に拈ける渡辺45,46)の業績 等から蛋白合成, 分泌, 吸収, 物質輸送を始め種々の細 胞機能上関係ある重要な構造であるとともに同一細胞内 においてすら種々な形態的様相を示するのであることが 知られている. また核膜，細胞膜，Golgi complex の膜 系等とも連絡することが知られ，最近では糸粒体の前駆 体といわれる Microbody もこの構造から出来ることが 明らかにされている15,36、37)，肝細胞にお汁る小胞体は。 大別して (1)表面に Palade 顆粒と呼ばれる 150〜200 Å の RNA に富も顆粒を伴つた厚さ $40 \sim 50 \AA$ の薄い膜:

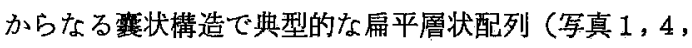
$5 ， 9 ， 10 ）$ を示し且つ内腔には均質で明るい無定形の. 内容質を含んでいるものと，(2)表面に顆粒を持たず形も 不規則小胞状ないしじゆず玉状，網状を呈するもの（写: 真 1，4，12）とがある. (1)は rough surfaced variety (Palade), 粗面小胞体 (渡辺), Ergastoplasmic sac (Weiss), a-cytomembrane (Sjöstrand) 等と呼ばれる むのに相当し, (2)は smooth surfaced variety (Palade)

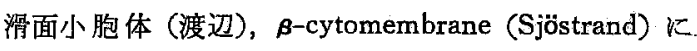
相当する，(1) と（2) とは互に連絡，移行を持ち細胞質の 啫塩基性と密接な関係があるといわれている，一般に既。 速の暗調細胞では (1)(2)のいずれもよく発達し 細胞質中: に遊離して存する Palade 顆粒も豊富で細胞質の腤調を きたす一要因をなしている（写真 $2 ， 3$ ），明調細胞では， 定型的な平行組状配列を示す粗面小胞体が采粒体とと女: に島噴状一塊をなして細胞質内の処々に認められること が多い(写真 $1,5,10)$.

\section{Golgi complex と中心体}

Dalton \& Felix47,48)により Golgi 装固が一般に(1)層: 状に配列する滑面 2 重膜 (lamella)，(2) 小顆粒または小 
菁胞 (granule または vesicle), (3)大形空胞 (vacuole) の 3 要素の組合せからなることが明らかにされて以来, Golgi complex なる呼称が広く用いられているが構成 要素相互と滑面小胞体系との間の遳絡像の認められるこ とから一部には Palade を始めこのものを独立した構造 物としてよりもむしろ滑面小胞采の一部として解釈しよ うといら考えむある. Golgi complexの機能については 古くから主として分泌に関保ありといわれているが腸上 皮などでは吸収にも関与しているようである. 写真 4 に 示すように肝細胞の Golgi complex では一般に大型 vacuole の発達はあまり認められず，位置的には毛細胆管 (Bc) およびこれに近い傍核部細胞質中に多くみ出され 胆汁分泌顆粒 $(\mathrm{Sg})$ の形成に関与しているよ5である15)

(写真 5 参照). 中心体の詳細な電顕的構造に関しては Yamada 49), de Harven \& Bernhard50) を始め種々の 細胞および時期について数多くの研究が行なわれてい る. その基本構造滵接した 2 本の細い Filament の一 対が 9 組輪状に集つて出来た小円筒で位置的には一般に Golgi 野にみ出されるものであるが不幸にして筆者らは まだ肝細胞における中心体の明膫な写真をえていない。

\section{E. 細胞表面の特殊構造と胆毛細管}

先に述べたように肝細胞の類洞側表面には Microvilli (Mv) と呼ばれる長さ約 $500 \mathrm{~m} \mu$, 直径約 $100 \mathrm{~m} \mu$ 程度 の不規則指状の細胞質突起が密生し，類洞内皮 (Edc) および Kupffer 氏星状細胞との間に Disse 氏腔 (Ds) に相当する不規則な間隍を形成している（写真 1，3）. このよ5な構造の発達は肝細胞以外でもたとえば小腸上 皮 (小皮縁相当)，堅近位迁尿細管上皮 (刷子緣相当) の 内腔側表面に見出されるが肝細胞ではその配列が不規則 な点が異なつている.その機能については当然のことな がらまず第一に物質交換面積の堌大が考えられるが Disse 氏腔内を流れる血浆ないしリンパ流の調節にも関 係を有するものと考えられる59,60). 一方 2 ないし 3 個 の肝細胞が互に相接する部分では細胞膜走行はほぼ平滑 で, 少数のホック様細胞岸合構造2) と少数の Microvilli を伴ら細胞間腺の限局性拡大により形成されたいわゆる 細胞間分泌小管としての胆毛細管 (Bc)（写真 $1 ， 4$, 5) および Bizzozero の結節 (Bn)51) (Desmosome) (写真 5 ) と呼ばれる上皮細胞結合構造がある. Bizzozero の結節は特に胆毛緗管の両端には必ず認められ相対する 2 枚の細胞膜の一部がこれと直接する両側細胞基啠筫の一 部とともに限局性に電子密度を增したものであつてこの 部分の細胞間腺も他部よりやや暗く且つ少しく狭いのが
普通である．注目すべきは閉鎖堤に相当すべき楧造即ら 細胞遊離面 (Disse 氏腔に向与部分) に接した部分にお ける Bizzozero結節様構造の存在は肝細胞ではほとんど 見出されないことである。これらの構造からみると肝細 胞相互の結合は他の上皮細胞の昜合に較べて弱いことが 容易に想像されるが事実これを裏書きするかのごとく急 激な電子線照射によりしばしば人工的に細胞間隙が抗大 するのが鏡検中に観察される．Rouiller 56)が報告した Disse 氏膑と胆毛細管との間の連絡像は強力な電子ビー 么の急激な照射による人工像であろう. 近年組織化学的 方法を加味した電顕的研究が次第に盛んになりつつある が Essner ら52) は胆毛細管壁細胞膜における ATP-ase および 5-Nucleotidase 活性と Disse 氏腔に突出する細 胞膜 (Microvilli) における 5-Nucleotidase 活性の存在 を顕出しているが，これら膜構造の分泌並びに吸収に関 する機能を考六合わせると甚だ興味深いものがある.

\section{F. 細胞質中に認められるその他の構造}

肝細胞質中には既述の細胞内小器官の他に種々な構造 物が正常でも認められる.ささに述べた明調細胞の細胞 質の淡明にみえる領域 (写真 $1, \mathrm{Ga}$ ) に相当して組織化 学的に Glycogen が豊富に存在すること2,8,53) が知られ ているが，この部分 (以下 Glycogen 領域と称する) を 詳細に観察すると(1)滑面小胞系に属する少数の小胞, (2) 内容の明るく拔けたよらな限界膜のあまり明らかでない 多数の小空胞様構造 (写真 6 , *印), (3)極めて電子密度 の低い無定形基質（写真 6 ，**印）および(4)少数の大い さ $55 \AA$ の極めて電子密度の高い球形小粒子（写真 6 ， Fg）が存在することがわかる. (4)はフェリチン顆粒54) であり明・暗・中間調いずれの細胞質内にもほぼビマン 性に分布し，その少数は系粒体基質中にも認められてい 万.

しかしながら残り (1)(2)(3)のいずれの部分に Glycogen が存在するかといら問題についてはまだ明らかな証拠は 示されていない. Porter ら53)は (2)に相当すべき構造を 重視し Glycogen の存在と密接な関係ありと考え, Glycogen unit なる語を用いている。篗者らは最近 VonGierke 氏病肝の穿刺生検材料の 2 例を観察し大体にお いて Porter らの意見に賛成しらる所見をえているが確 証をらるためには組織化学的方法を併用した今後の研究 にまたねばならないであろら。

胆毛細管周囲の細胞質中には一見 Microbody に似た ほぼ同大同形の顆粒状構造（写真 4，5参照）が散在し ているが薄い切片により詳細に観察すると(1)被膜と内容 
$2: 4$

肝

質との間に明るい輪罣があること，(2)前述フェリチン顆 粒に酷似した小粒子を多数含むこと，(3)内容質の一部が しばしば月蝕様の明るい欠損を示し胆毛細管に近づくほ どこのような特徵ある欠損を示すものの多いこと（写真 5 ), (4) 胆毛細管周囲だけに䖵められること等の理由か ら筆者ら 15,37) 扎よび萩原36) は胆汁の分泌顆粒と解釈し ている. Novikoff ら55) は遠心分離によつて肝細胞から Lysosome に富んだ分劃を作りこれを電顕的に観察して “dense bodies”といわれる構造を多数認めているがこ のものは上述の胆汁分泌顆粒と酷似した像を示してい る.

その他細胞質内にしばしば認められる構造物としては 脂肪滴がある、これは一般に強いオスミック酸還元性を 持つために電子密度が極めて高く，大いさは正常では数 $\mu$ 程度までで類球形ないし不規則星状を示すが化学的組 成からみた脂肪の種類と電顕像での特徽についての問題 はまだ充分に解決されていない，また，脂肪滴形成の機 序についても従来明らかではなかつたが最近 Suzuki56) により乳クリームを注胃したマウス肝蔵では脂肪小滴 (20〜80 m $\mu$ ) は Disse 氏腔に達した後, Microvilliの 間の細胞膜嵌入に始まる Pinocytosis56)により細胞内に 摂取されこれが滑面小胞系により深部に輸送され且つ また滑面小胞体内腔に蓄積されることにより大型脂肪滴 が形成される過程を明らかにし，同時に糸粒体が脂肪代 謝に関与しつつあると考完られる興味ある像をむ発表し ている.

\section{類洞の構造と Disse 氏腔}

肝類洞の構造と Disse 氏膑の存否については, 従来幾 多の議論の繰返されてきたところであり，電顕的にも Braunsteiner58), Fawcett2), Rouiller6), Parks7), 高木 $5^{9)}$, 橋本 510), Takaki et al59), 田口60), Rüttner 511) および山岸12)らにより観察されている.これら諸報告 の中，初期のものは類洞血が值接肝細胞に広い範围に亘 つて接している像を報告し，また Disse 氏腔の存在を否 定しているもの58)もあるがそれ以後のものでは類洞腔 は広く伸展する内皮および Kupffer 氏星状細胞の層に より被われ処々に小孔ないし小裂腺（500～2000 Å) があり，また内皮薄層がしばしば部分的重積を示すこと から血獎のみは Disse 氏腔に流入しらるものと考える者 が多い。これは標本作製手技の問題から初期には類洞壁 の構造を完全に近い焱で保存することができなかつたた めであろ5.肝類洞は写真 $1,3,7$ に示すよ5に薄く伸展
2 巻 1 号 $(1960)$

した仢皮 (Edc) および Kupffer 氏細胞の一層により被 われ，既述たし肝細胞表面の Microvilli (Mv) との間に 不規則に連続する間腺を形成している. その巾は広いと ころでも約 $500 \AA$ 程度であつて光学顕微鏡的には勿椧 認めえない：これは従来からその存否を論議されてきた Disse 氏腔 (Ds) に一致するものである.被覆内皮層には 処々に Kupffer 氏星状細胞に相当する細胞質括よび小器 官が豊富でしばしば種々の貧食物と多くの突起とをるつ 細胞を介在せしぬ，また部分的俊接内皮細胞またはK氏細胞と重積している部分もあるが内皮がSyncitialであ るといら証披は認められない，内皮細胞層は最も薄く伸 展した部分（写真 1，3，7）では厚さ約 $300 \AA$ ときにそ れ以下の值を示し，しばしば上述重積部の他に明らかに 小孔または小裂腺と考克られる 500〜2000 ̊程度の不 連続部を認めることができる。内皮細胞および K一氏星 状細胞の外側（Disse 氏腔内）には少量の Collagen filaments が存在するが基底膜に相当する連続した膜状構 造はなく，両細胞の基底例細胞膜は比較的平滑で值 接 Microvilli の上に位置しており Microvilli との間に何ら の直接的関係を示ささいが細胞質の豊富な部分では基底 側の内皮または $\mathrm{K}$ 一氐細胞の細胞膜は不規則に出入して 細胞突起を形成し肝細胞表面の Microvilli との間に緾 絡像即ち内皮細胞の固定機構7)が認められる.

\section{中心静脈，胆管膨大部，門脈領域 および肝小葉リンパ系}

写真 3 は 1 と同一例のラッテ肝小葉中心静脈 (Cv) の 一部を示方弱拡大写真で $2 つ$ 類洞 $\left(\mathrm{S}_{1}, \mathrm{~S}_{2}\right)$ が流入す る部分を示したものである：この写真からす明らかなよ らに中心静脈壁は基底膜を伴ら伸展した内皮層 (Edc) (類洞内皮に移行)，その外側を被５細長い平滑筋細胞

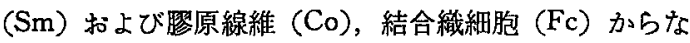
り，流入部類洞壁の膠原線維量は中間帯類洞壁のそれに 比盿すると甚だ多い，写真 7 は門脈領域を示す弱払大連 続写真で写真左上部には直接肝細胞に隣接すると同時に 拡大した胆毛細管 (Bcp) を囲んで表面に少数の Microvilli をもつた明るい胆管上皮細胞 (Bep) があり，中 央には数個の明るい胆管上皮に囲まれた小胆管腔 (B1) が認められる。

この切片には現われていないがこの胆毛細管腔と小胆 管腔とは互に連絡を有するものと考えられまたこの部が 膨大部に一致するものであろう。この膨大部胆管上皮は 隣接肝細胞とは全く異なる性格を持ら，細胞は明るく糸 
粒体および小胞体の発達も肝細胞に比して著るしく劣つ ている.膨大部および小䏣管の基底部は基底膜 $(\mathrm{Bm})$ によ つて被われて扣り右上隅にみえる門脈枝 (Vp) の壁には 内腔側から扁平な内皮層, 基底膜, 線維細胞 $(\mathrm{Fc})$ が存在 するがこの军真には平滑笳細胞は示されていない，特に 注目すべき所見としては，(1)膨大部胆管上皮が突然に肝 細胞に隣接していること, (2)小胆管および膨大部を構成 する胆管上皮下には明らかに基底膜があるが，これに接 する類洞壁には基底膜がみられないこと(*印), 即ち類洞 内皮下の Disse 氏腔が膨大部ないし小胆管基底膜外の 組織間隙に直接連絡していることである。従来肝臓のり ンパ系については墨汁等の逆行性注入により小胆管周囲 まではリンパ管が追求されていたが，小葉内のリンパ系 に関しては色素注入の困難なことから明らかではなかつ た61)．Disse 氏腔および膨大部に関する既㮏の所見，お よび肝リンパが組成的に血漿に似た蛋白を含むといら Bollmann 562) の報告を考穴合わせる墨汁注入による Disse 氏腔の逆行性造影の失敗は同腔に無数に突出する 肝細胞表面の Microvilli が注入された墨粒子を濾過し あるいは弁膜様作用を示すことにより中枢側への逆行性 流入を阻止したためであつて肝小葉内リンパは Disse 氏 腔に始まり，Microvilli の存在によつて極くゆるやかに この部を流れて門脈領域小胆管周囲の組織間陌に入り次 いでリンパ管に流入するものであろらと想像される.

\section{飢餓および食餌組成による肝細胞像の変動}

正常肝細胞の微細構造を把握する上にず食慨条件に よる变動を充分に理解することが必要なことは改めて説 くまでもないと思われるがこのよらな考虑のもとに筆者 らは最近(1)飢餓 5 日までのラッテ肝細胞の遂日的变化, (2)飢餓 5 日後に再び飢餓前と同じ混合食剘 (標售食)15) を与えた場合，(3)高糖質食を与えた場合，出高脂肪食を 与えた場合，(5)高蛋白食を与えた場合（第 1 表参照)15） 等についてて肝細胞像の変動を観察中てあるが以下これら の条件下に护るる肝細胞 (中間帯) の電顕像を簡単に紹 介し正常変動理解の参考に供したい。

\section{A. 飢餓時の肝細胞像}

飢餓時における肝細胞笪顕像は既に Bernhard63,64)， Gansler 565)，Fawcett2) その他により一部紹介されて いるが変化は主として細胞質に限られ，その特徽は時間 的推移にすよるが総括して次の変化に要約される. 即ち (1) Glycogen 領域および Glycogen unit が減少して不明 になること，(2)粗面小胞体が次第に定型的な平行層状の
表 1. 食剘組成表

\begin{tabular}{|c|c|c|c|}
\hline \multicolumn{2}{|l|}{ 標準食 } & \multicolumn{2}{|l|}{ 高糖質食 } \\
\hline 小 麦 & $78 \mathrm{~g}$ & 小 & $91 \mathrm{~g}$ \\
\hline ミルクカゼイン & 10 & ミルクカゼイン & 10 \\
\hline- & 3 & マカラム塩 & 5 \\
\hline$\checkmark カ ラ \Delta$ 塩 & 1 & 朋 & 1 \\
\hline 油 & 5 & 醉 & 3 \\
\hline 醉时 & 3 & & \\
\hline 高蛋白食 & & 高脂肪食 & \\
\hline ミルクカゼイン & $101 \mathrm{~g}$ & F & 35 \\
\hline$\checkmark カ ラ \Delta$ 塩 & 5 & ミルクカゼイン & 10 \\
\hline 油 & 1 & マカラム，塩 & 5 \\
\hline 酵 & 3 & 肝 & 1 \\
\hline & & 과 & 3 \\
\hline
\end{tabular}

（註）各食触共 $350+\alpha \mathrm{Kal}$.

(但し $\boldsymbol{\alpha}$ はマカラム塩 $5 \mathrm{~g}$, 肝油 $1 \mathrm{~g}$, 醉母 $3 \mathrm{~g}$ に よるもの)

配列を示さず粗開分散短小化してゆくこと，(3)粗面小胞 体絶対量の減少，(4)粗面小胞体表面の Palade 顆粒の脱 落，遊離傾向（写真 9 矢印）(5)滑面小胞体系の減少（た だし暗調細胞では豊富) (6糸粒体は減少しないが膨化お よび Cristolysis (高木)15) (写真 $8, \mathrm{M} 1,2 ， 3$ )を 示す, (7) Microbody の増加, (8) 暗調細胞の堌加, (9) Golgi complex の萎縮, (10) 胆汁分泌顆粒の減少々胆毛 細管の涨小，(11)Microvilli の萎縮等が挙げられる。最 近 Arakawa66)により Ethionine を投与したラッテ肝細 胞で(4)とほとんど一致した所見が認められているが, 粗 面小胞体ならびに Palade 顆粒が蛋白合成と密接な関係 を有する事赛および Ethionine の蛋白合成抑制作用を背 景としてみる時，飢餓㘧よび Ethionine 投与時の粗面小 胞体の变化は甚だ興味深い所見であろら。

\section{B. 再標準食投与による肝細胞像}

飢餓 5 日後に再び混合食餌を与えた場合の変化は大約 すれば A.の各変化の回復とい.うことになるが必ずしも 完全にもとの過程を同じ速度で逆にたどるとはいえな い. 即ち(1)糸粒体の膨化は数時間後には汪漼回復するが (2)Microbody はなおかなり遅くまで多数認められる。そ の他, (3) Glycogen 領域の増大および Glycogen unit の 発現，(4)粗面小胞体の增加と定型的平行紐状配列を示す ことおよび滑面小胞体の増加，(5) 遊離 Palade 顆粒の 減少，(6) 暗調細胞の減少，(7) Microbody の減少， (8) Golgi complex の発達回復, (9) 胆计分泌顆粒の增加 と毛細胆管腔の復旧払大，(10) Microvilli の発達回復等 
$2: 6$

肝

の変化が認められる，完全に細胞像が断食前に復帰する のは一般に約 10 日後であるが系粒体の膨化回復のみは 甚だ速やかである.

\section{C. 高糖質食投与による変化}

飢餓 5 日後から高糖食を与えた場合の変化は写真 10 そ 示すごとくほぼ混合食䬲を再投与した場合のそれに類似 するが Glycogen 領域 (Ga)および Glycogen unit の急 激な拡大増加とともに類球形あるいは不規則な形をるつ 特致的な構造（写真 27 *印)の增加が顕著である.これは 比較的大型 $(1 \sim 3 \mu)$ でしばしば周辺のみ甚だ電子密度 が高い，中心部は明るく無搆造または周辺部と同様な少 量の電子密度の高い細顆粒状物を容れ，正常標準混合食 飼育時肝細胞などで時に認められる均質で甚だ電子密度 高く薄切時に觟の出来やすい脂肪滴とは異なつたもので ある.この構造の本態については現在明らかでないが, 強いオスミック酸還元性をもつことと Sudan 沿染色に 上る光学的所見から広義の脂肪滴に属せしむべきもので はないかと考えられる. Glycogen 領域は時間を経るに 従つて増々払大し，その結果定型的配列を示す粗面小胞 体 (REr) を始め糸粒体，遊離 Palade 顆粒等は細胞質 内において島懙状に限局して存在するよ5になる.こ のような像は最近筆者らが経 験したVon-Gierke 氏病 肝細胞の像によく似ている.

\section{D. 高蛋白食投与による变化}

この場合もやはり系粒体の膨化は速やかに回復する. 粗面および滑面小胞体も再び增加するが標準混合食を投 与した場合に比較するとその発達は比較的弱く，粗面小 胞体の平行紐状配列む顕著でなくしばしば個々の紐状粗 面小胞体 (REr) が各釆粒体 (M) 周㬰を取巻いて配列す る㑯向がある(写真 11). 特徵的な所見としては類円形で 中等度の電子密度をむち大いさ数 $\mu$ に達する類球形小体 がしばしば多数細胞質中に見出されることと細胞質基質 に電子密度低く限界不明瞭で不規則斑状観を呈する極め て铛細な顆粒状物（写真 11 *印部）が認められ，釆粒体， 小胞体その他の諸構造の間を均一に埋めていることであ る.これらの構造の発現ないし細胞質に挏ける諸変化が 高蛋白食として与えたミルクカゼインに由来する特異的 なものであるかまたは一般蛋白食慨の多量摄取によつて も起こりらるものであるか否かについてはこれらの構造 の本態とともになお検討中である.

\section{E. 高脂肪食投与による変化}

この場合の変化の特幑としては第一に細胞質内におけ る脂肪滴の多数発現にあることは当然であるう.これら
2 巻 1 号 (1960)

脂肪滴(写真 12, F) 弾層の限界膜に包まれその内部は (1)均質で甚だ電子密度の高いもの：(2)電子密度は中等度 で細顆粒ないし細フィラメント様を呈する物質により満 たされているものがある. (1)と(2)との美異は恐らく局所 固定条件の差によるものであろう. 粗面㧍よび滑面小胞 体の発達はあまり認められない，粗面小胞体 (REr) は 高榶食および標準混合食を与えた場合のような定型的平 行紐状配列を示さず，また Glycogen 領域は䚾とんど認 められない.

\section{おわりに}

以上肝臟の電子顕微鏡像の一般を概略紹介し， 特に肝細胞電顕像の生理的变動を理解するための 一助として飢餓および糖質，脂肪，蛋白質をそれ ぞれ多量に含む食慨の再投与による像変化の概略 を示した．勿論これのみによつて複雑多枓な機能 を持つ肝細胞像を充分に理解することは不可能事 であり，今後に残された重要な問題はなお数多く 存する筈であるが，このささやかな小文が肝臓研 究に携わる方々のために聊かでる奇与するところ あれば筆者らにとつてこの上ない喜びであろう。 誌面の都合上説明不充分のそしりは免れがたいが 詳細については各文献をご参照載きたい.

\section{文献}

1) Dalton, A. J. et al. : J. Nat. Cancer Inst., 11 : 439, 1950. 2) Fawcett, D. W. : J. Nat. Cancer Inst., $15: 1475$, 1955. 3) Oberling, C. et Rouiller, C.: Ann. d'Anat. path., 1 : 401, 1956. 4) Palade, G. E.: J. Biophysic. and Biochem. Cytol., 2 (suppl.): 85, 1956. 5) Palade, G. E. \& Siekevitz, P.: J. Biophysic. and Biochem. Cytol., 2 : 171, 1956. 6) Rouiller, C.: Acta anat., 26 : 94, 1956. 7) Parks, H.F.: Electron Microscopy; Proc. Stockholm Conf., Sept. 1956. 8) Bernhard, W. et Rouiller, C.: J. Biophysic. and Biochem. Cytol., 2 (suppl.) :73,1956.9) 高木文一ほか：日本病理学会誌, $46: 262,1957$. 10）橋本正淑注加：電子顕微鏡，6:109, 1957. 11) Rüttner, J.R.\& Vogel, A.: Verh. d. Dtsch. Ges. f. Path., 41 Tagg., S. 314, 1958. 12) Yamagishi, M.: Arch. hist. jap., 18: 223, 1959. 13) Rouiller, C.: Ann. d'Anat. Path. 2 : 548, 1957. 14) Brown, D. B. et al. : Gastroenterology, 32 : 103, 1957. 15) 高木女一: : 第 15 回日本医学会総会学術集会 


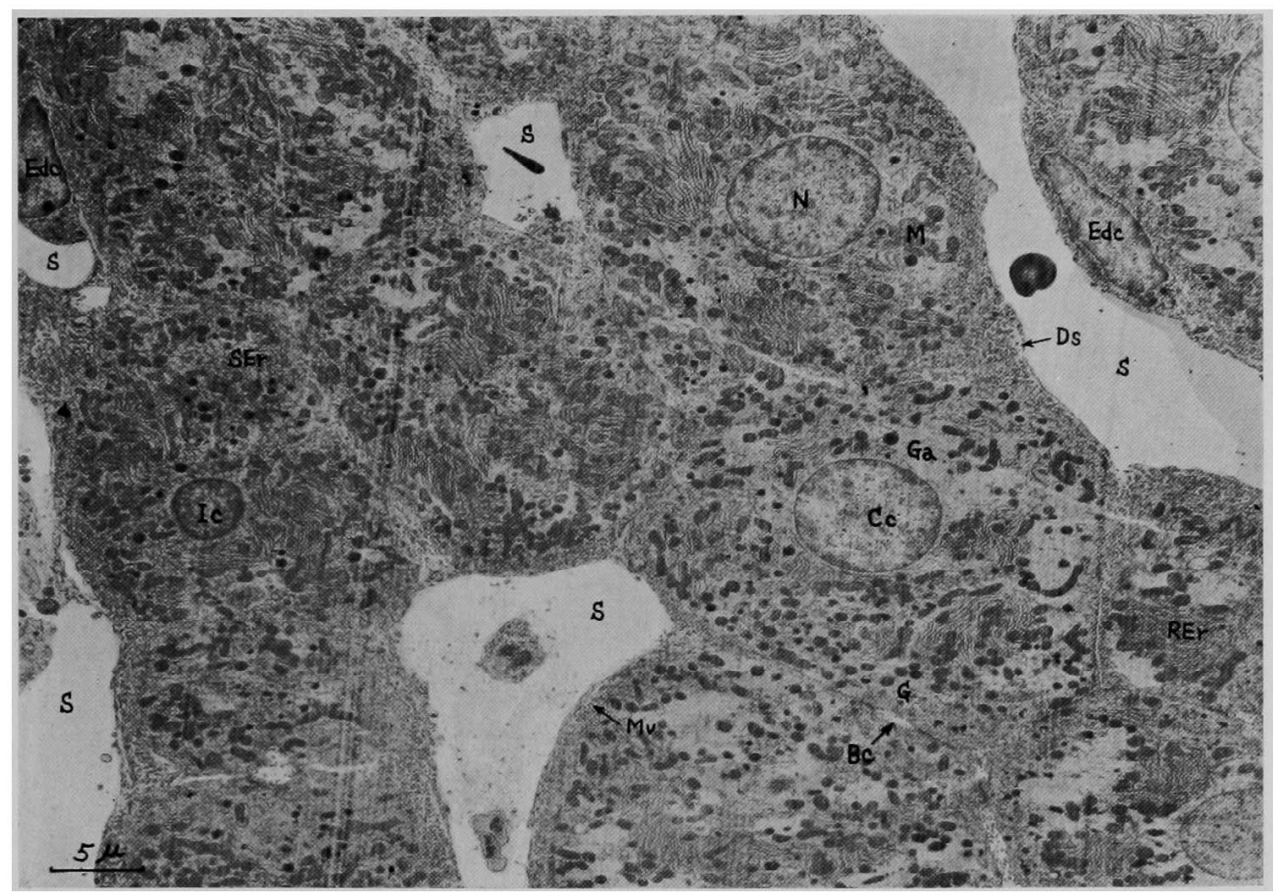

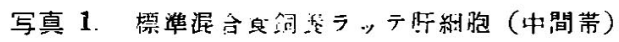

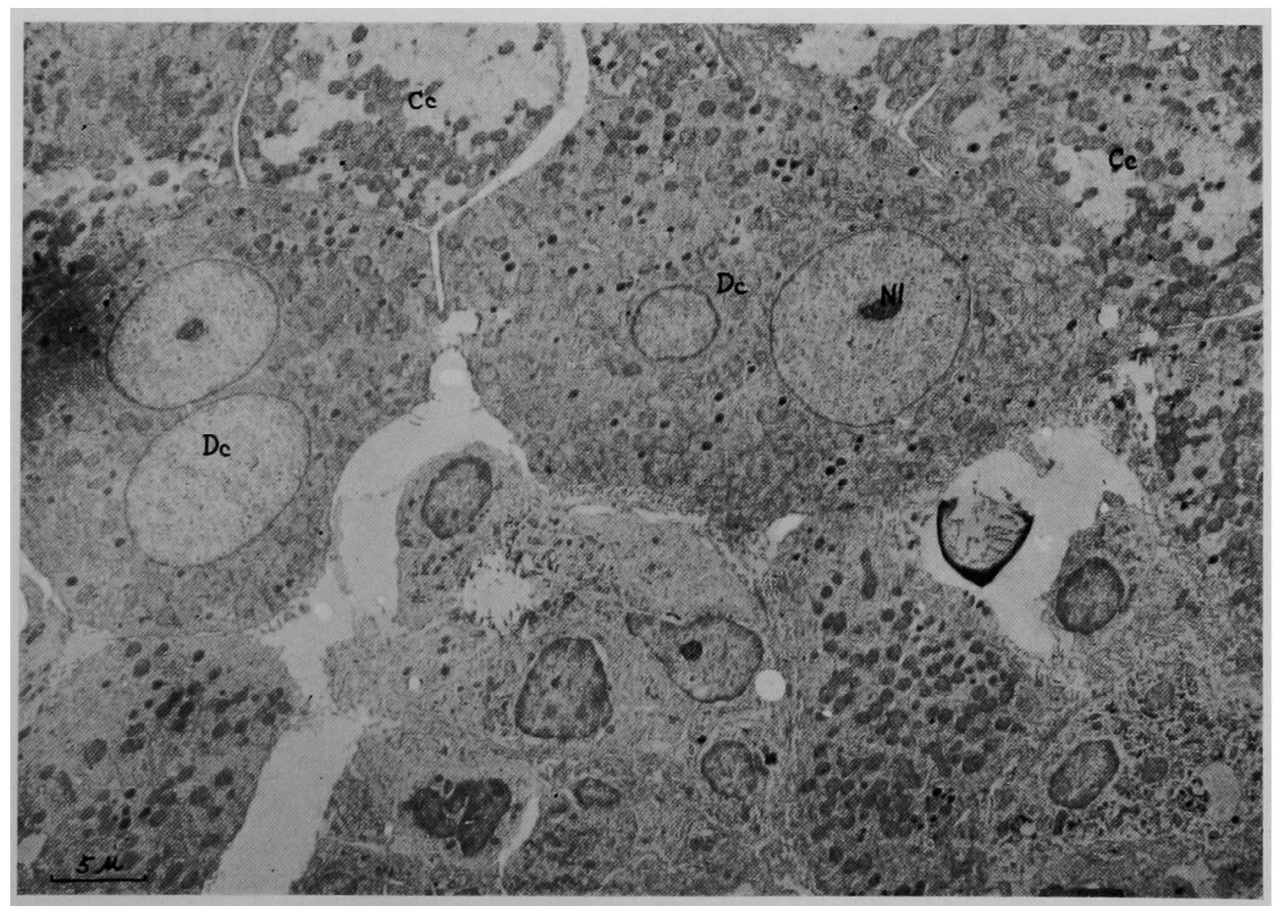

写真 2. 標準混合食飼巍ラッテ肝細胞（周辺帯） 
$2: 8$

肝 臟 2 巻 1 号 $(1960)$ )

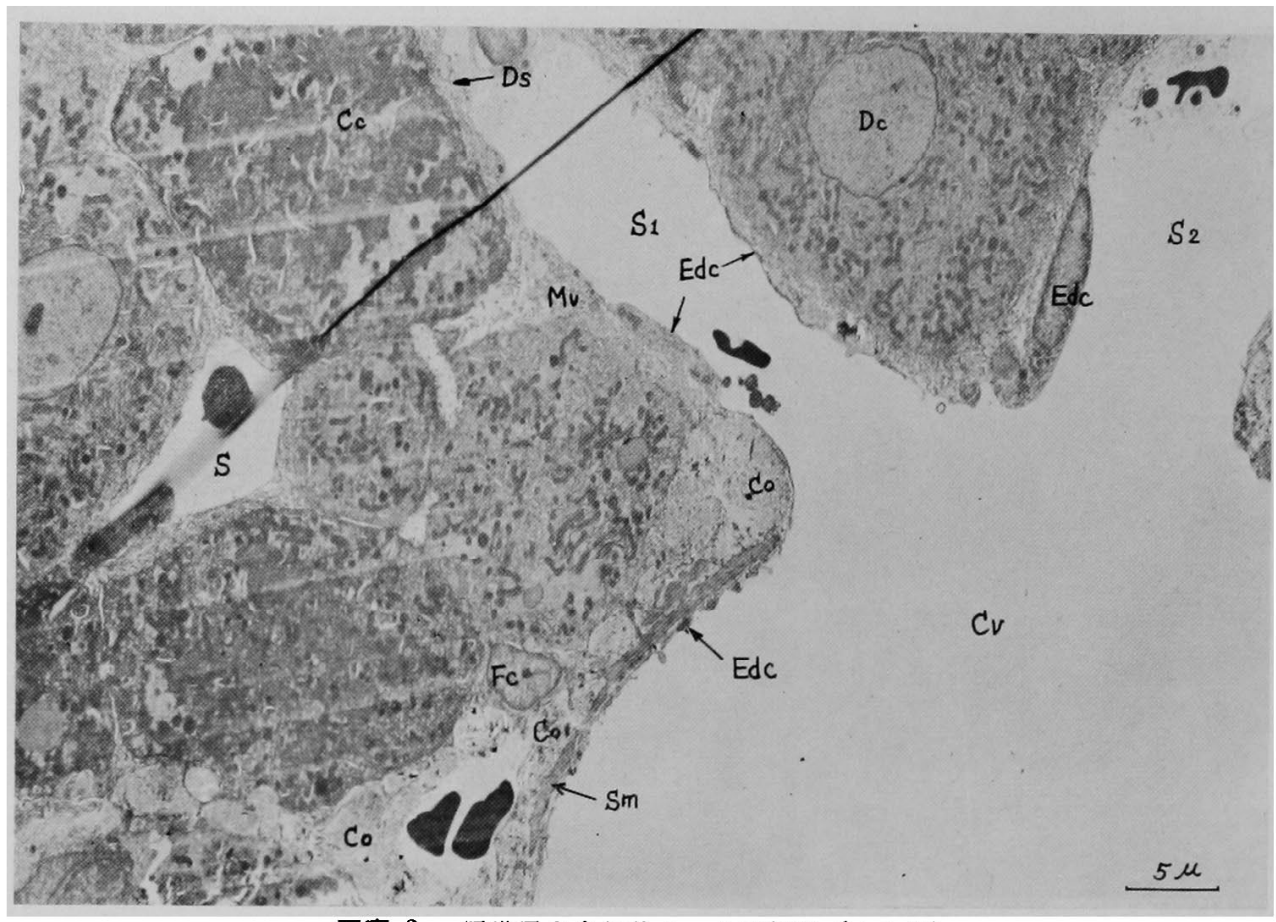

写真 3. 䧣準混合食飼養ラッテ肝細胞（中心帯）

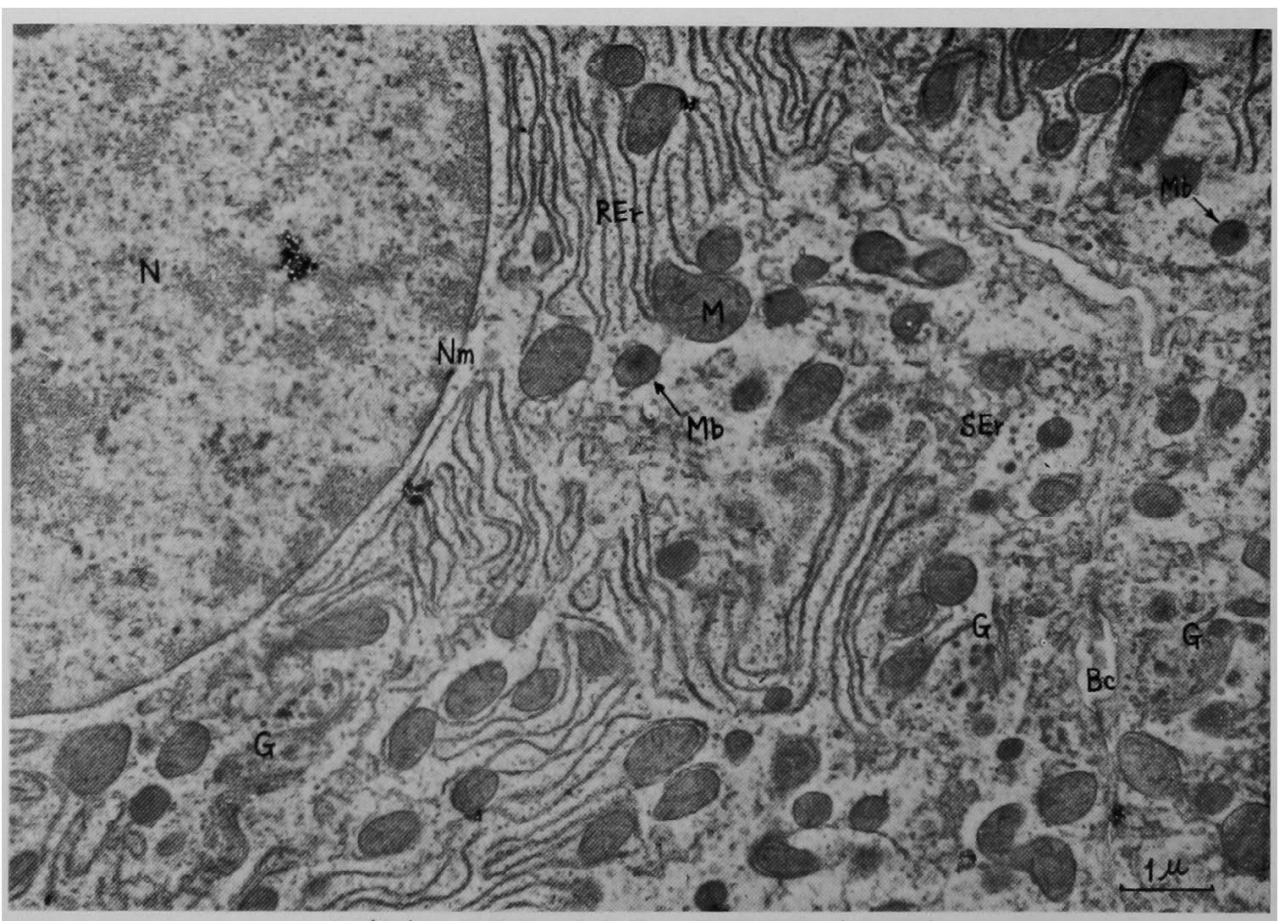

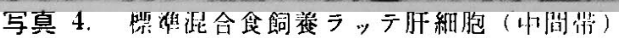




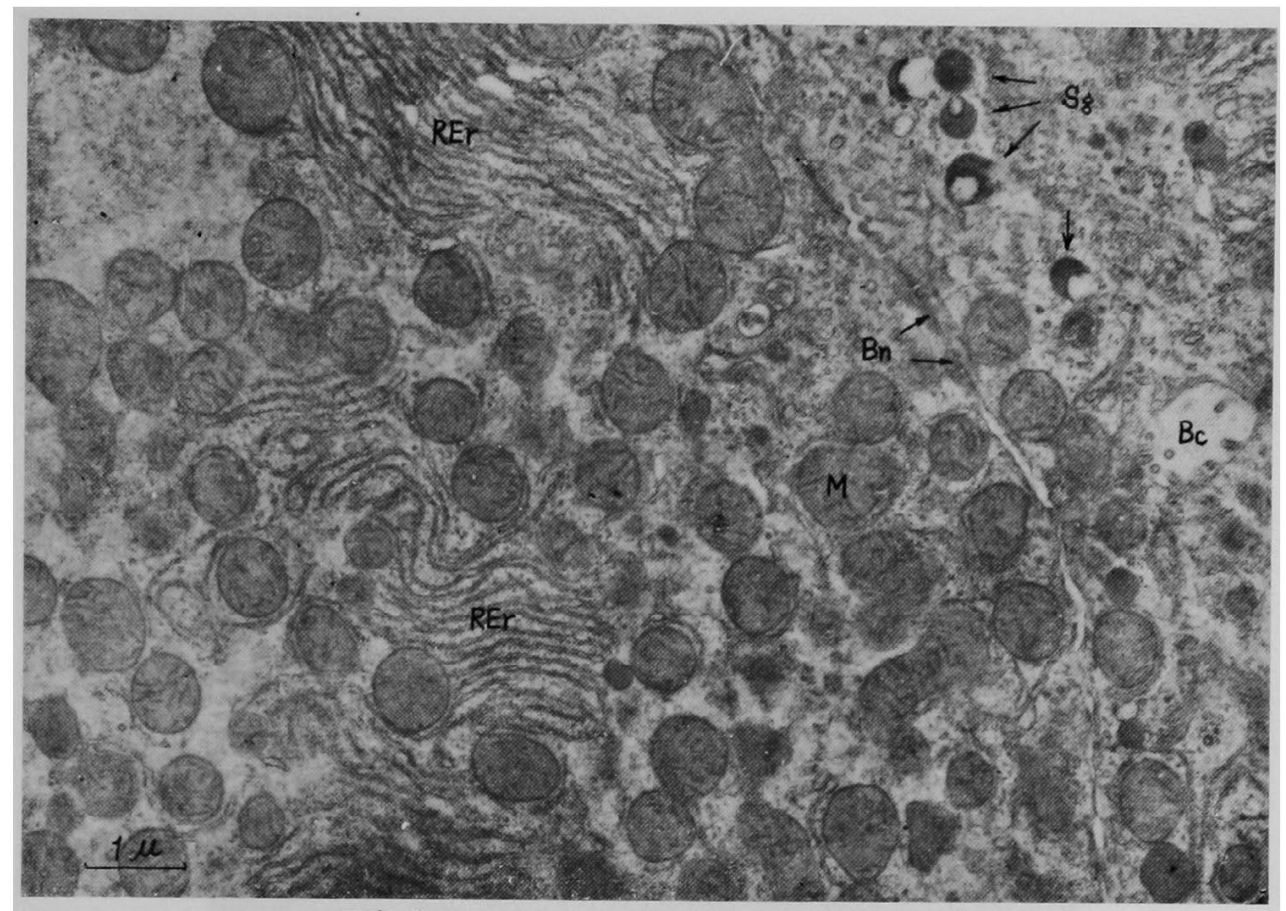

写真 5. 標準涮合食飼養ラッテ肝稩胞（中間帯）

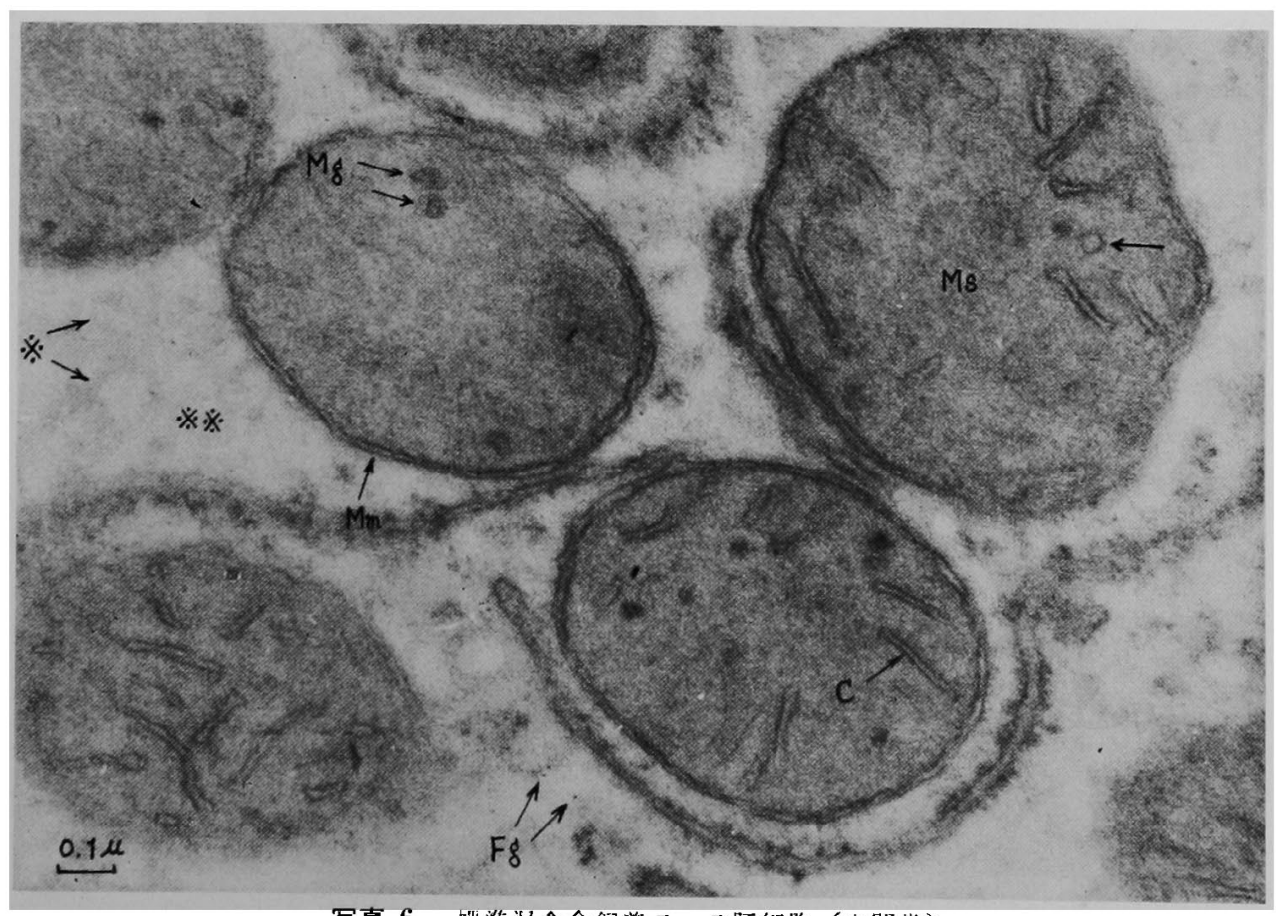

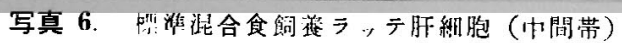


肝臟 2 巻 1 号 $(1960)$

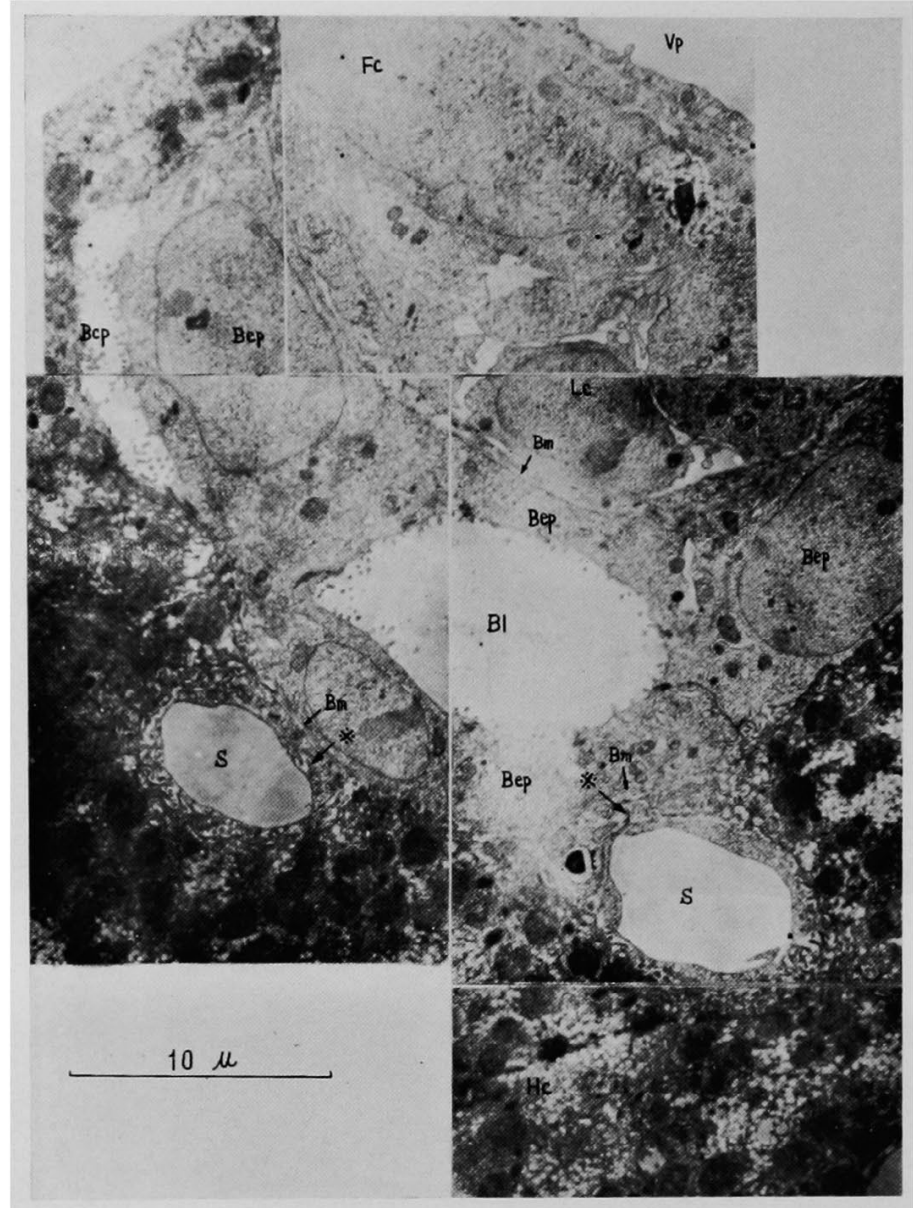

写真 7. 雑食飼裳マウス肝臓师脈領域

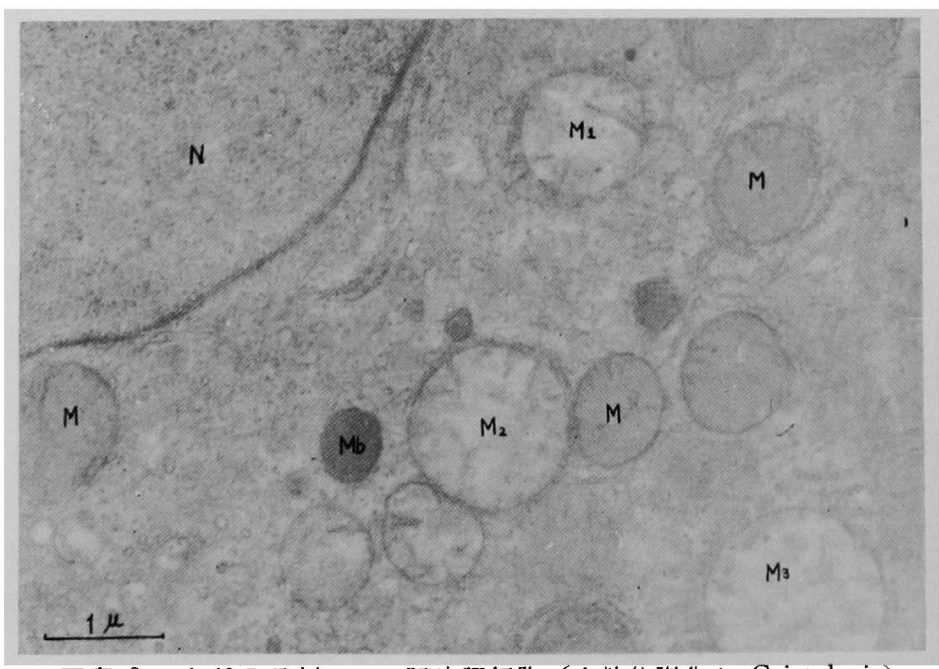

写真 8. 䬣餓 5 下例ラッテ肝瞕調細胞（系粒体膨化とCristolysis） 


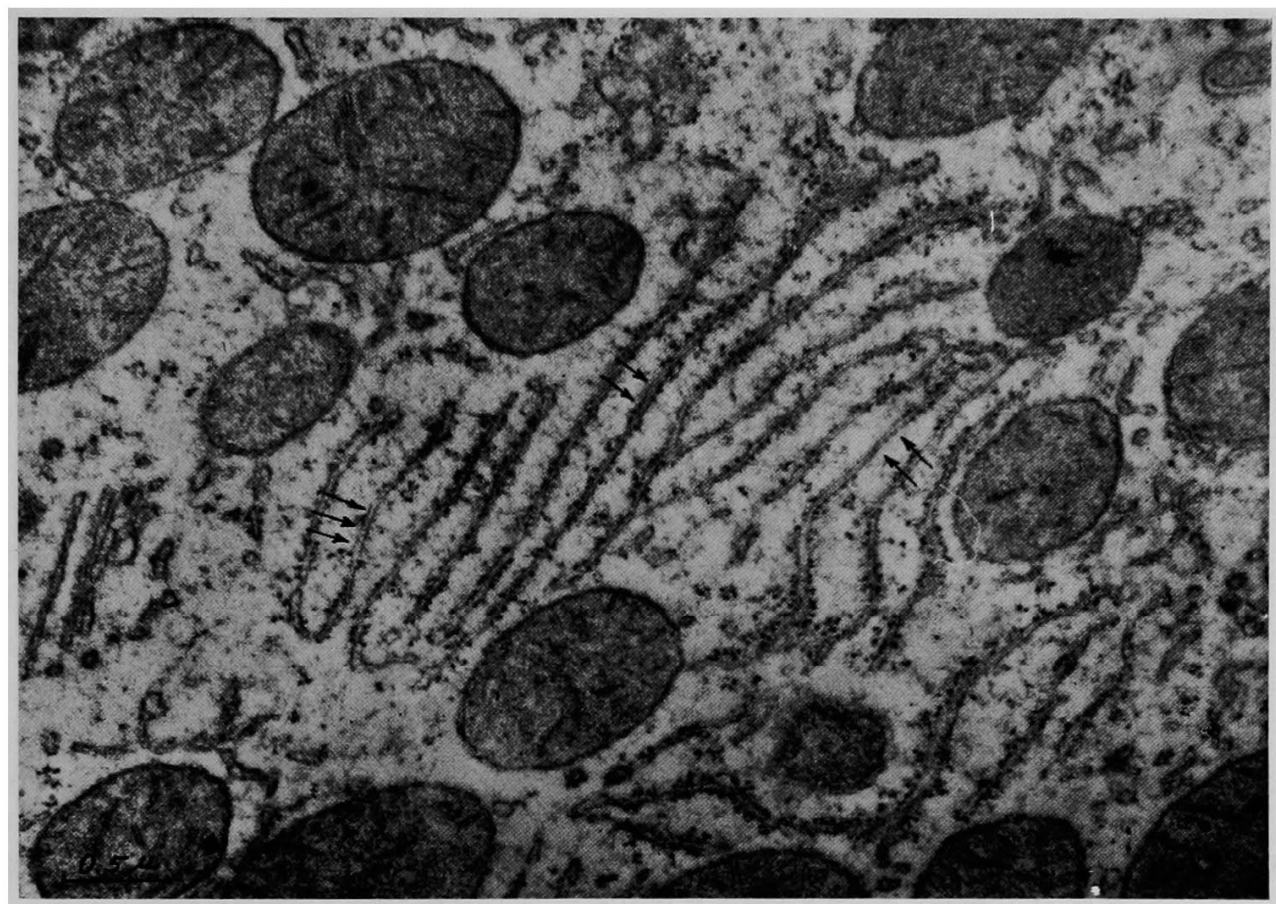

写真 9. 飢餓 48 時間後ラッテ肝練胞

(Palade 顆粒の脱落を示す)

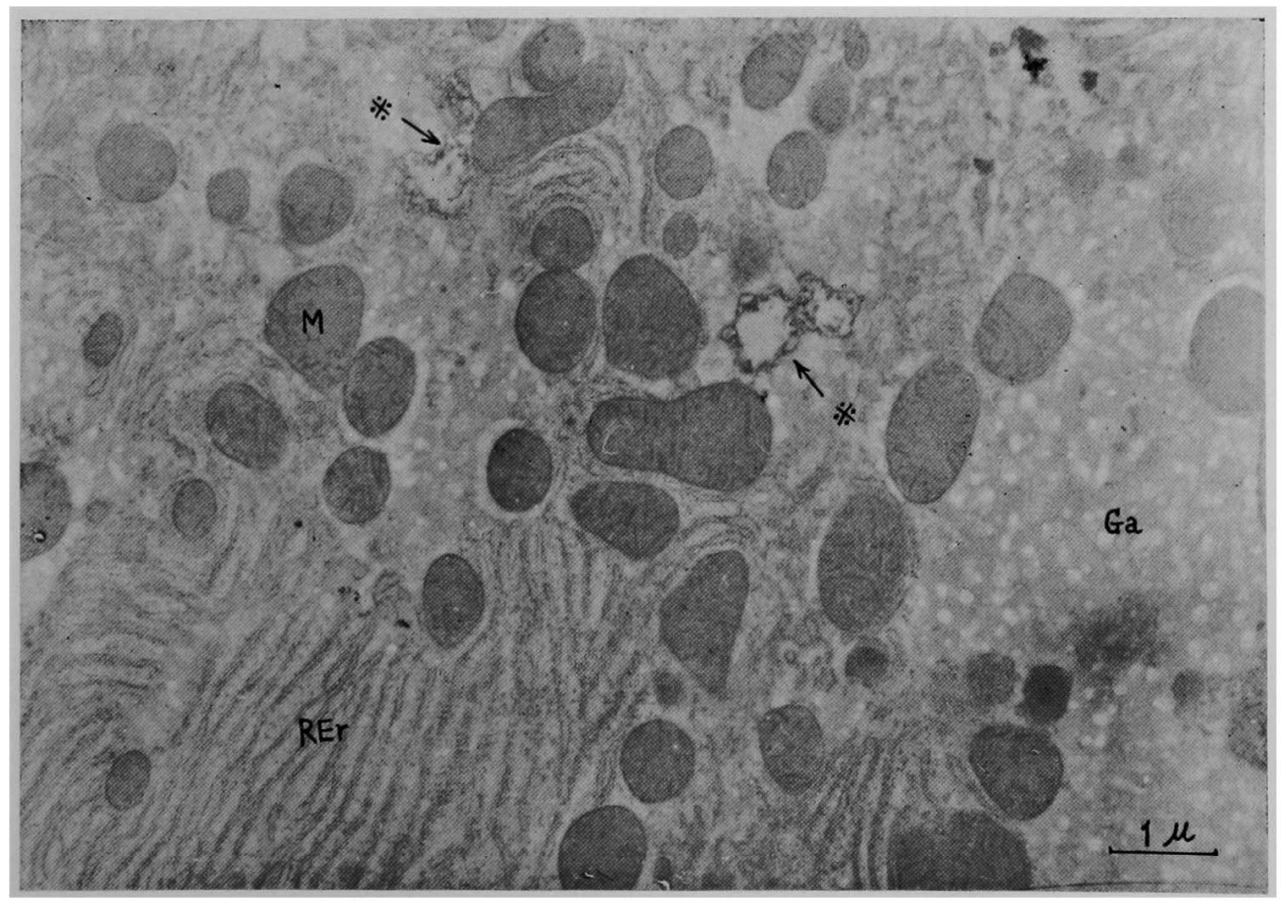

写真 10. 飤餓 5 日 $\rightarrow$ 高䏸質食飼養 12 時間後ラッテ肝細胞 


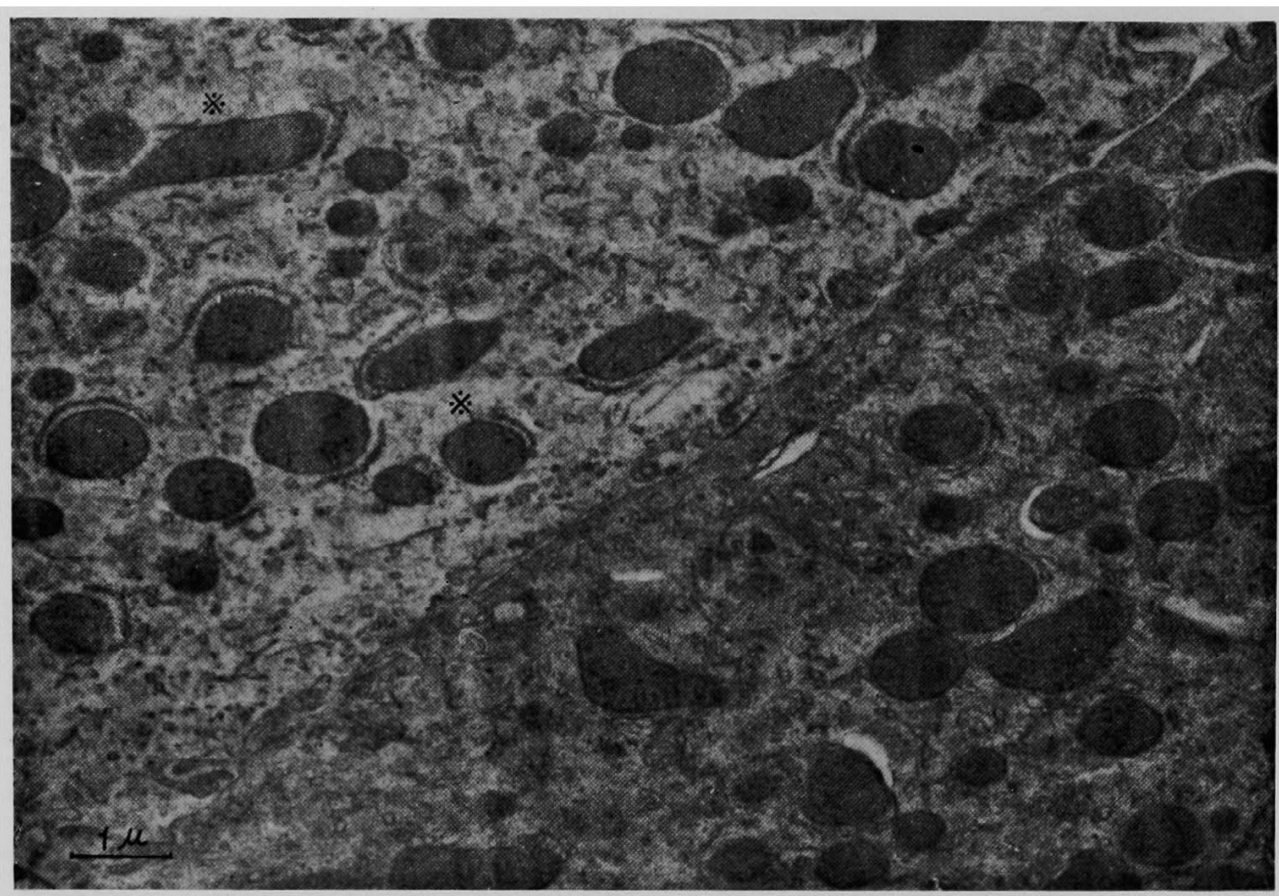

写莫 11. 飤餓 5 日 $\rightarrow$ 高蛋白食飼養 10 日後ラッテ肝細胞（明抢上び暗調細胞）

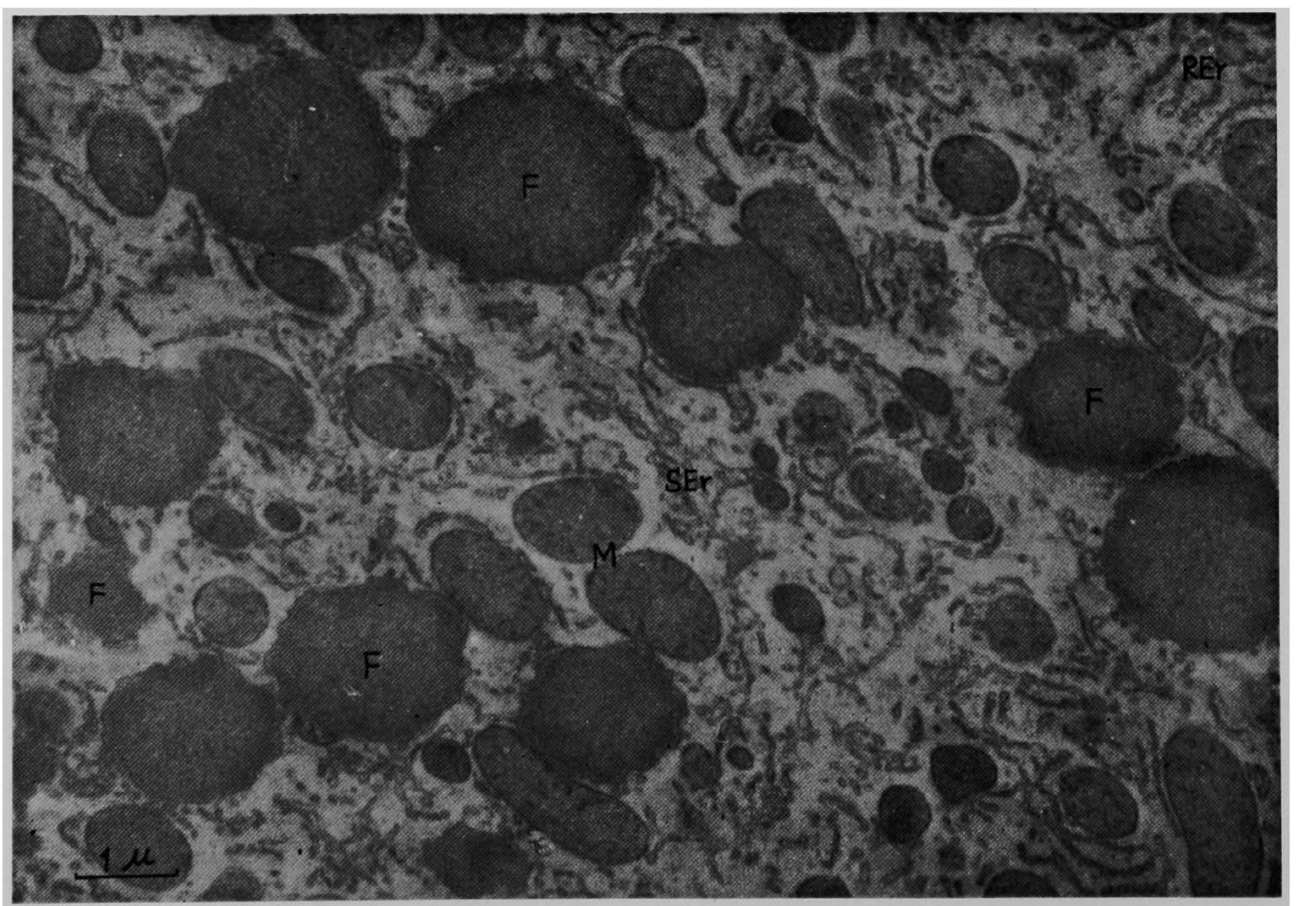

写真 12. 飢餓 5 日 $\rightarrow$ 高脂肪食飼萑 10 日後ラッテ朋細胞 
記錄, vol. I, p. 70, 1959. 16) Watson, M. L. : J. Biophys. and Biochem. Cytol., $1: 257,1955.17$ ) do. : do. $6: 147,1959$. 18) Afzelius, B. A.: Exp. Cell Res., 8 : 147, 1955. 19) Amano, S. et al. : Cytologia, 21 : 241, 1956.20$)$ Sjöstrand, F.S. \& Hanzon, V.: Exp. Cell Res., $7:$ 393, 1954. 21) Suzuki, T.: Gann, 48 : 39, 1957. 22) Estable, C. \& Sotelo, J.R.: Inst. Inv. Cien. Biol. Pub., 1: 105, 1951. 23) Borysko, E. \& Bang, F. B.: J. Appl. Phys., 23 : 163, 1952. 24) Bernhard, W. et al. : Experimentia, 8: 5, 1952. 25) Bernhard, W. et al. : Exp. Cell Res., 9 : 88, 1955. 26）田中春高：日血会誌, $20: 237,1957.27)$ Anderson, E. \& Beams, H. W. : J. Biophysic. and Biochem. Cytol., 2 (suppl.) : 439, $1956 . \quad 28$ ) Palade, G. E. : Anat. Red., $114: 427$, 1952.29$)$ do. : J. Histochem. and Cytochem., $1:$ 188, 1953. 30) Sjöstrand, F.S.\& Rhodin, J.: Exp. Cell Res., $4: 426,1953$. 31) Cedergren, E.A.: J. Ultrastructure Res., supp. 1, pp. 97, 1959. 32) Noël, R.: Axch. d'Anat. Micro,, $19: 1$, 1923. 33) Noël, R. et Pallot, G.: Bull. Histol. appl. Physiol. et Path., 10: 169, 1923. 34) Rouiller, C. \& Bernhard, W.: J. Biophysic. and Biochem. Cytol., 2 (suppl.) : 355, 1956. 35) Rhodin, J.: Correlation of ultrastructural organization and function in normal and experimentally changed proximal convoluted tubule cells of the mouse kidney., Privately printed for the Department of Anatomy, Karolinska institute, Stockholm, by Aktiebolaget Godvil, Stockholm, 1954. 36) 荻原明 : 東京慈恵会医科大学雑誌, $75: 637,1959$. 37) Takaki, et al. : Jikei Med. J. (in press) 38) Porter, K. R. et al. : J. Exp. Med., 81 : 233, 1945.

39) Porter, K.R.\& Kallman, F.L.: Ann. New ;York Akad. Sc., 54: 882, 1952.40 ) Palade, G. E. \& Porter, K. R. : Anat. Rec., 112: 370, 1952.41$)$ Palade, G. E.: J. Exp. Med., 95 : 285, 1952.4 42) Palade, G. E. \& Porter, K. R. : J.Exp. Med., 100: 641, 1954.
43) Weiss, J. M. : J. Exp. Med., $98: 607$, 1953. 44) Sjöstrand, F.S.: Physical Techniques in Biological Research, Vol. III. Acad. Press Inc. New York, 1956. 45）渡辺陽之輔：電子顕制竟，4：49, 1955. 46) Watanabe, Y. : Journal of Electronmicroscopy, 3: 43, 1955. 47) Dalton, A. J. \& Felix, M. D.: Am. J. An-

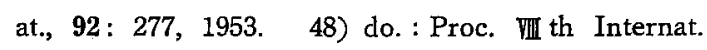
Cong. Cell Biol., Leiden, 1954, in Fine Structure of Cells, New York. Interscience publishers, Inc., 1956, 274. 49) Yamada, E. : Acta anatomica, 29: 267, 1957. 50) de Harven, E. et Bernhard, W.: Z.Zellforsch., 45 : 378, 1956.51$)$ Porter, K. R. : Anat. Rec., $118: 433,1954 . \quad 52)$ Essner, E. et al.: J. Biophysic. and Biochem. Cytol., 4 : 711, 1958. 53) Porter, K.R. \& Bruni, C.: Cancer Res., 19: 997, 1959. 54) Kuff, E. L.\& Dalton, A. J. : J. Ultrastructure Res., $1: 62,1957$. 55) Novikoff, A. B. et al.: J. Biophysic. and Biochem. Cytol, 2 (suppl.) : 179, $1956 . \quad 56$ ) Suzuki, Y.: Journal of Electronmicroscopy (in press). 57) Bennett, H. S. : J. Biophysic. and Biochem. Cytcl, 2 (suppl.) : 99, 1956 . 58) Braunsteiner, H. et al. : Ztschr. f. d. ges. exper. Med., 121 : 254, 1953. 59) Takaki, F.et. al.: Jikei Med. J. (in press) 60) 田口 舜一：東京慈恵会医科大学雑䞑, 74:2605, 1959 . 61) Maximow, A. A. \& Bloom, W.: Textbook of Histology, 7th Edition, Saunders Co., New York, 1957. 62) Bollman, J. L. : Liver Injury; Transactions of the 9th Conf., Editor; F. W. Hoffbauer, Josiah Macy, Jr. Foundation. New York, 1951. 63) Bernhard, W.et al. : Z. Zellforsch., 37 : 281, 1952. 64) Bernhard, W. et al. : Arch. anat. micr. et morphol. exp., $43: 236$, 1954. 65) Gansler, H. et Rouiller, C.: Schweiz. Z. Path. Bakt., 19 : 217, 1956. 66) Arakawa, K. : Journal of Electronmicroscopy, 8: 54, 1960, 67) 高木 文一, 鈴木昭男：メディカル・カルチュフ, 1(3): 120 1960. 